\title{
Gay and Lesbian Parents: No Longer a Paradox
}

\author{
Brian J. Dew \\ Jane E. Myers
}

The authors discuss parenting as a normative developmental issue for gay and lesbian individuals. Issues and choices that affect decisions concerning parenting, implications for counselors, and suggestions for research are discussed.

During the past decade, alternative family forms have increasingly challenged the conceptual myth of the traditional nuclear family (Flaks, Ficher, Masterpasqua, \& Joseph, 1995; Harrison, Wilson, Pine, Chan, \& Buriel, 1990; Ivey, 1991). Researchers have historically assumed that the most favorable home environment for rearing children is provided by two-parent families. It has also been assumed that these two parents are heterosexual (Ricketts \& Achtenberg, 1990). However, existing research concludes that homosexual parents are not rare and that their number is increasing (Bailey, Bobrow, Wolfe, \& Mikach, 1995; Dunne, 1987; Masters \& Johnson, 1979). Researchers have estimated that the number of gay or lesbian parents in the United States ranges from 2 million to 8 million, whereas estimates of children of gay or lesbian parents ranges from 4 million to 14 million (Patterson, 1992). Bigner and Bozett (1990) and Patterson (1994) conclude that a more definite figure is impossible to determine because of the difficulties associated with identifying gay and lesbian parents.

Sexual minority parents and gay and lesbian individuals who want to become parents encounter various challenges in their efforts to accomplish the normal developmental task of parenting. Ricketts and Achtenberg (1990) postulated that every gay or lesbian parent who wants to parent endures "the glare of media publicity or the scrutiny of judicial or administrative review" (p. 85). Judgment regarding one's fitness as a parent, for the gay or lesbian individual, is often precipitated by fear, which is based on negative and pervasive stereotypes.

Brian J. Dew is president of In Speak Communications in Grecnsboro, North Carolina. Jane E. Myers is a professor at the University of North Carolina-Greensboro. Correspondence regarding this article should be sent to Brian J. Dew, 306 North Lindell Rd., Suite D, Greensboro, NC 27403 (e-mail: briandew@aol.com), 
In this article, we review the choices that sexual minorities have when considering parenting. We discuss developmental issues regarding the gay and lesbian individual's desire to parent, review available options for sexual minorities who want to parent, and explore consequences of parenting for the gay or lesbian individual. Implications for counselors working with this population are considered, and recommendations for needed research are discussed.

\section{DEVELOPMENTAL ISSUES AND PARENTING: WHAT IS "NORMAL"?}

Although most gay and lesbian individuals become parents as a result of an opposite-sex relationship during which children are produced, increasing numbers of gays and lesbians are becoming parents outside prior heterosexual contexts (Mallon, 1998). In particular, more gays and lesbians are consciously completing the developmental task of becoming parents while maintaining a positive homosexual identity (Mitchell, 1996; Pies, 1990; Rohrbaugh, 1988). In this section, developmental issues and parenting within the context of same-sex relationships are examined. Developmental theorists study behavior in an attempt to determine what is "normal." These theorists also attempt to distinguish between the biological, psychological, and social bases of behavior. An overview of development during the periods when most people engage in parenting may establish a baseline for what is normal, against which the salience of parenting for gay and lesbian individuals can be gauged.

The search for identity in adolescence and young adulthood has been the focus of extensive research and has resulted in a variety of theoretical perspectives (Chickering, 1993; Erikson, 1963; Marcia, 1987; Perry, 1970). The conclusion from this research is that the process of identity development is lifelong and universal, affecting all developmental stages of the life span. In addition, researchers have addressed the unique developmental needs of homosexual individuals regarding identity issues (Cass, 1979; Fassinger \& Miller, 1996; Troiden, 1989). Although the dynamics of identity development may differ for gay and lesbian individuals, the process of identity development is the same regardless of sexual orientation (Robinson \& Barret, 1986).

Following the successful development of one's identity, according to Erikson (1963), the establishment of intimate relationships becomes the central task of young adulthood. Failure to meet this task results in loneliness and isolation. Furthermore, individuals who fail to establish intimate relationships during young adulthood will experience problems meeting subsequent developmental challenges. Havighurst (1973) also recognized the early adult years as the time to marry and establish a family. Such theories have been questioned in recent years, because they were generally 
based on studies of White men living in heterosexual family structures. As family structures continue to evolve, the question of normal development in young adulthood may also evolve. Currently, however, there is widespread agreement that the establishment of intimate relationships is a central developmental challenge for young adults. This assertion is supported by research that shows that marriage is the most important factor in happiness, exceeding work, friendships, or other aspects of life (Papalia, Camp, \& Feldman, 1996). It apparently is not the legally binding marriage, per se, that is crucial; rather, it is engagement in a mutually committed relationship that mitigates for or against personal happiness. Such relationships are as possible for gay and lesbian as for heterosexual individuals (Allen \& Demo, 1995; Benkov, 1994).

Similarly, developmental researchers have found that "the desire for children is almost universal. This urge is not limited to married people" (Papalia, et al., 1996, p. 345). Schaie and Geiwitz (1982) reflected on the nature of childbearing before the development of contraceptives, noting that the most basic reason people have children is that "nature has made sex enjoyable, nearly irresistible, . . . couples engage in sexual intercourse, and babies appear on the scene soon thereafter" (p. 45). They also provided evidence that the search for contraceptives to prevent pregnancy is one of society's longest struggles, suggesting that the biological urge to parent is not the only reason for having children. Additional factors cited in their research include social and personal satisfaction. From a social perspective, children contribute to the welfare of and help protect and care for the family. From a personal perspective, children provide a means of satisfying the basic human need to achieve generativity (Erikson, 1963).

There is nothing in developmental theory or existing studies to suggest that sexual orientation is related to the lack of a search for identity, the lack of a need for intimacy in young adulthood, or the absence of needs for generativity during the middle and later years. In addition, although gay and lesbian youth experience unique developmental struggles, there is no research to suggest that individuals who are gay or lesbian experience developmental needs that are any different than those of their heterosexual peers. Therefore, it is clear that the desire to parent may be viewed as a normal developmental need, regardless of sexual orientation. What is surprising is not that $10 \%$ $20 \%$ of gay and lesbian individuals are parents, but rather that more adult gay and lesbian individuals do not have children. We agree with researchers who state that the number of homosexuals who are parents may be expected to increase (Bailey et al., 1995; Dunne, 1987; Masters \& Johnson, 1979). Counselors who work with gay and lesbian individuals may be most helpful to them if they understand both the available options for becoming a parent and barriers that interfere with an individual's ability to assume this common, normal life role. 


\section{PARENTING OPTIONS FOR THE GAY OR LESBIAN INDIVIDUAL.}

Most gay and lesbian individuals who are parents today first became parents during heterosexual relationships, most before realizing their homosexual identity or coming out (Mallon, 1998). However, as more gay and lesbian individuals choose to parent outside heterosexual relationships, the need to explore alternative methods of parenting arises (Fraser, Fish, \& Mackenzie, 1995). The primary options available to them for parenting include donor insemination, foster parenting, single individual adoption, and co-parent adoption.

\section{DONOR INSEMINATION}

Donor insemination is the medical procedure in which the surrogate mother is artificially inseminated with a donor's sperm. The donor's sperm is used to fertilize the ovum either outside or inside the women's body. Consequently, the child is genetically related to the surrogate mother. Most lesbians who selecting donor insemination as the preferred form of impregnation (Noble, 1987; Patterson, 1994; Rothberg \& Weinstein, 1996). An individual who decides to become a parent through donor insemination may choose a friend, relative, or acquaintance to be the sperm donor or may choose to use sperm from an unknown donor (Patterson, 1992). Robertson (1996) suggested that when the donor is known, the potential mother may or may not share parental responsibilities with the father. Patterson (1992) concluded that donor insemination "with known or unknown sperm donors has only recently been made widely available to unmarried heterosexual women and to lesbians" (p. 1027).

Although we could find no literature to support donor insemination as an existing option for gay men, reports from the media, friends, and clients reveal this procedure to be an increasingly viable method for gay men to become parents. Gay men wishing to become parents through donor insemination have two options. They can voluntarily donate sperm to a surrogate mother. Under this choice, legal documents are prepared before the procedure and describe parenting roles and responsibilities of each parent. Alternately, gay couples that select donor insemination may use sperm from both partners so that the parenting experience can be shared. The search for a surrogate mother may involve a woman who is known to the gay man or couple or one who is located through surrogate agencies.

\section{FOSTER PARENTING}

A second parenting option for gay or lesbian individuals is foster parenting (Ricketts, 1991; Ricketts \& Achtenberg, 1990). Children who are placed 
with their state's Department of Family and Children Services increasingly need supportive and loving homes in which to be raised. An advantage to this form of parenting includes receiving the child more quickly than through other methods (e.g., donor insemination; McPherson, 1993).

Successful attempts of gays and lesbians to become foster parents have often hinged on an individual's ability to work with bureaucratic social service delivery systems (Ricketts \& Achtenberg, 1990; Shernoff, 1996). Each state's department of social services (DSS) differs on its interpretation of the feasibility or desirability of gay and lesbian foster parenting. In California, each county has a branch of DSS that decides the interpreration of gay and lesbian foster parenting (Ricketts, 1991). Consequently, in counties that have a more liberal constituency, more progressive policies exist regarding foster parenting by sexual minorities. In contrast, Florida passed legislation in 1977 that statutorily prohibited gays and lesbians from foster parenting and adoption (Achtenberg, 1985). New Hampshire, 10 years later, passed a ban on gay and lesbian foster-care parenting; that ban remains. Florida and New Hampshire continue to be the only two states that actively ban gay men and lesbians from becoming foster parents (Mallon, 1998).

A growing number of public and private agencies are beginning to view lesbian and gay homes as appropriate placements for homosexually identified youth (Ricketts \& Achtenberg, 1990). In most cases, however, agencies are reluctant to place adolescents with same-sex households. In certain cases of gay or lesbian-identified youth, sexual minorities are allowed to foster-parent a child only if the youth has a confirmed same-sex sexual orientation (Kleber, Howell, \& Tibbits-Kleber, 1986; McPherson, 1993). Ricketts and Achtenberg (1990) mentioned cities such as Los Angeles, New York, and San Francisco, which have established programs to find placements for gay and lesbian youth who enter foster care programs and who have had unsuccessful prior placements because they are gay. However, either sexual minority-identified youth or heterosexual youth may be placed successfully in gay and lesbian foster homes.

\section{SINGLE INDIVIDUAL. ADOPTION}

Rules regarding qualifications for adoptions also vary considerably from state to state (Rothberg \& Weinstein, 1996). Although many states have allowed adoptions by single adults, many gay and lesbian individuals maintain secrecy regarding their sexual orientation to avoid discrimination (Patterson, 1994). In choosing adoption, the potential gay or lesbian parent must decide between agency adoption and independent adoption. The agency adoption process involves a private or public adoption agency evaluation of the home and placement of the child with the prospective adoptive 
parent(s). The adoption agency then makes a recommendation to the court, which has the power to make the ultimate decision regarding the adoption.

An independent adoption allows the natural parent(s) to choose for themselves the person with whom they want their child placed. Following the placement of the child, a state or private agency investigates the prospective home and makes the official recommendation to the court. The court, as in the case of an agency adoption, makes the final decision regarding granting or denying the adoption. Most gay and lesbian adoptions have occurred through independent adoptions (Shernoff, 1996). By choosing an independent adoption, potential gay and lesbian parents avoid waiting in lines at an agency that will more than likely give preference to married couples.

It is generally recommended that potential gay or lesbian adoptive parents inform the biological parent of their homosexual orientation before consent is given for the adoption (Kleber et al., 1986). If the biological parent(s) learns, after consent has been given, that an adoptive parent is gay or lesbian, the agreement might be voided because information has been withheld.

\section{CO-PARENT ADOPTION}

It has historically "been assumed that no agency would recommend and that no court would grant a joint adoption by an unmarried couple" (Ricketts \& Achtenberg, 1990, p. 108). However, a 1986 California court decision approved the recommendation of that state's DSS to allow adoptions by two lesbian couples. However, this action and its subsequent political backlash led to the passage of regulations by the California Department of Social Services that restricted placements to environments where the couple demonstrated a relationship symbolized by a legal marriage (City of Los Angeles, 1988).

An additional issue in co-parent adoption involves the legal outcome when nonmarital cohabitants share parenting duties when one of the partners is the child's legal parent (Colberg, 1996). In this scenario, the legal non-cohabiting parent may consent to the adoption by a gay or lesbian co-parent without giving up any of his or her own parental rights. However, in most cases involving two legal parents, one must give up his or her rights before adoption by a third person (McPherson, 1993). Only recently, however, have courts begun to consider cases in which the two biological parents retain their legal rights while granting rights to a third party, such as a gay or lesbian individual who partners with a parent from a prior heterosexual relationship (Colberg, 1996).

\section{CONSEQUENCES OF BEING A GAY OR LESBIAN PARENT}

Although it is apparent that parenting for gay and lesbian individuals is a normal developmental process, there are consequences that sexual minority 
parent(s) encounter. In particular, the psychological and social environments of the gay parent are viewed by many to be dichotomous and contradictory. Consequences of being a gay or lesbian parent include identity concerns, discrimination from heterosexuals, and discrimination from inside the gay and lesbian community.

\section{Identity Concerns}

Bigner and Jacobsen (1989a) concluded that gay fathers have both a unique and more complex process of identity development than do other gay men and nongay fathers. In describing the gay farher's role as "a victim of divided personal identity," the authors identified concerns of gay fathers that often hinder their choice to parent. Bigner and Bozerte (1990) determined that the process of identity development for the gay father requires a reconciliation of two polar extremes. The authors concluded that gay fathers can be characterized as "marginal beings who are challenged by having ties to the cultural worlds of both nongay[s] and gays" (p. 157). Because each identity is essentially unaccepted by the opposite culture, the process of "integrative sanctioning" is required to integrate both identities into the cognitive structure of "gay father." Bozette (1980) concluded that for the gay father a positive integration of identities involves the process of disclosing his gay identity to nongays and his father identity to gays. Bozette (1979) further discovered that gay fathers who were sexually active with the same sex before being married reconciled their gay and father identities more readily than did those who were not. In contrast, gay fathers who first began to act on their same-sex desires after marriage had considerable difficulty resolving this perceived identity conflict.

\section{Discrimination From Heferosexuals}

Other parenting issues often faced by gays and lesbians involve relationships with children and the coming out process; relationships with teachers, schools, and agencies; and stigma management for the child. Bozette (1987) concluded that gay fathers disclose to their children for three reasons: (a) enhanced closeness that fosters a mutually supportive and intimate relationship between father and child; (b) incongruity of keeping a gay identity hidden from such a permanent relationship; and (c) the difficulty, based on more frequent contact between father and child, of hiding one's same-sex sexual orientation. He also suggested three reasons that gay fathers choose not to disclose to their children: (a) fear of rejection because of one's same-sex sexual orientation, (b) the father's rejection of his gayness, and (c) fear of retaliation from a former wife.

Gay and lesbian parents often have to confront institutionalized homophobia and homoprejudice when dealing with a government agency or the child's school. For example, Sears (1991), in a study of more than 400 
prospective teachers, discovered that $80 \%$ had negative feelings toward lesbian and gay students. Furthermore, the author discovered that more than one third of these prospective teachers were considered "high grade homophobics" based on their completion of the Index of Homophobia Scale. Intake and other required forms for government agencies may have a heterosexual bias when asking for information related to the child's parents (Fassinger, 1991). Consequently, gay and lesbian parents may take a more passive role in their child's educational endeavors or fail to take advantage of existing government services.

The gay and lesbian parent must be aware of srigma management for the child because he or she has a sexual minority parent or parents (Dindia, 1998). Cain (1991) found that more than $90 \%$ of the fathers he sampled recognized the need for discretion in expressing their homosexuality to protect their children from harassment. Green (1978), in a study of lesbian mothers, found that only 3 of 21 children had been harassed as a result of their mother's homosexuality. However, Riddle and Arguelles (1981) discovered that $79 \%$ of the children of gay parents in their study had received homophobic messages from their peers about their parent's sexuality. Consequently, a parent's ability to discuss with his or her child the ramifications of having a gay or lesbian parent may be helpful in alleviating the stress associated with intense peer pressure.

\section{Discrimination Within the Gay and Lesbian Community}

In addition to discrimination from the heterosexual community, many gay and lesbian individuals endure discrimination from within the gay and lesbian community. Bigner and Bozett (1990) concluded that is was not uncommon for gay fathers to experience discrimination and rejection from other gays. Noting that gay culture is often singles-oriented, the authors emphasized the importance of personal freedom and autonomy within the gay community. Bozett (1987) concluded that gay fathers might have difficulty developing long-term, committed relationships with men who will be willing to accept children as a central issue in the relationship. Gay fathers are often seen as having emotional and financial responsibilities to others, time restrictions, and obligations to others who are dependent on them (Frommer, 1996). These factors could potentially result in feelings of jealousy by the nonparent partner. In addition, children may be an emotional and financial link to a previous marriage or heterosexual relationship, and potential partners may not want to battle for attention or be secondary to their partner's children (Bigner \& Bozett, 1990; Frommer, 1996).

\section{IMPLICATIONS FOR COUNSELORS}

Parenting has been defined in this article as a normal developmental challenge. Therefore, it is not surprising that increasing numbers of gay and 
lesbian individuals are choosing to become parents. Individuals who wish to or do become parents face the typical challenges of this role. In addition, being gay or lesbian and a parent, or a "want-to-be" parent, creates additional challenges that might lead the gay or lesbian individual to seek counseling. To be adequately prepared to meet these needs, counselors must first examine their own views of families and parenting. Counselors need to know of available resources and they must be aware of significant developmental issues, parenting options, and consequences that sexual minorities encounter when parenting or wishing to become parents. Finally, an understanding of the unique challenges confronting this population will contribute to the development of effective interventions.

Any mental health professional who provides clinical services to sexual minority parents must initially look at his or her own biases and perceptions of the family. Ricketts and Achtenberg (1990) appealed for greater flexibility in conceptualizing the family when they encouraged mental health professionals to adopt a definition of family "that simply reflect(s) the ways in which people live" (p. 84). The prevailing image of the American nuclear family that is held by both the public and the media seems more myth than reality because alternative family forms continue to emerge. Families made up of gay and lesbian parent(s) are just one form of an alternative family structure. Counselors must also be aware of the research that refutes the assumption that gay or lesbian parents are generally unfit to function in a parenting role.

In addition to examining one's own possible homophobia and heterosexism to expand the vision of "family," the counselor needs to be aware of available resources to help gay and lesbian parents and their children. Counselors can become critical sources of both support and guidance. The isolation and discrimination from outside and inside gay and lesbian communities mean that many gay or lesbian parents lack the social support of other gay and lesbian parents. Knowledge of support groups and other referral sources are often helpful to sexual minority parents. Hundreds of support groups for lesbian and gay families exist throughout the country including the Gay and Lesbian Coalition International, Parents and Friends of Gays and Lesbians (PFLAG), and other support groups designed specifically for gay and lesbian individuals. Knowledge of supportive medical professionals, including doctors, nurses, and fertility clinic workers, as well as representatives in the legal profession, may be critical resources for sexual minority clients who are parents or who want to parent.

Counselors need to be aware that increasing numbers of gays and lesbians are fulfilling their developmental tasks of adulthood and entering parenthood while holding on to their gay or lesbian identity. In particular, mental health professionals need to know that there is little data to suggest that there are differences between the developmental needs of people who 
are gay or lesbian and those who are heresosexual (Miranda \& Storms, 1989). In addition to the developmental aspects of gay and lesbian parents, mental health professionals must be aware of the options that are available to gays and lesbians who want to parent. Sufficient knowledge of a state's foster care and adoption policies is helpful in assessing the client's efforts toward parenthood. In particular, a counselor needs to be able to distinguish berween agency and independent adoption services as well as single parent and co-parenting adoption. Helping the client choose the option of parenthood requires the counselor to be knowledgeable of a variety of methods that are available to the gay and lesbian client.

The mental health provider also needs to be aware of the multiple consequences that face gay individuals who are already parents. Knowledge of both gay and lesbian identity and parental identity developmental concerns are important in helping the client integrate often conflicting values. Discrimination from the heterosexual and from within the gay and lesbian communities is common and may need to be addressed therapeutically, using such techniques as role playing, cognitive restructuring, and systemic family therapy.

Gay and lesbian parents will face the same developmental needs and challenges as heterosexual parents, including the need to parent effectively and to relate to partners, children, teachers, health care professionals, and others. In addition to these normative challenges, being gay or lesbian creates additional issues that counselors can help address. Bias against gay or lesbian parents may have a negative impact on relationships with partners, peers, social service providers, and children if timely interventions are not provided.

Counselors need to be aware of the variety of challenges that often confront partners of gay parents. Because many gay parents enter into samesex relationships after becoming parents, the nonparent partner may experience competition from his or her partner's children. Couples counseling is often therapeutic in resolving feelings of jealousy and fears of abandonment. Mental health professionals who work with this population need to be skilled in providing couples therapy. If counselors do not feel confident in their couples counseling skills, they need to be aware of referral sources that support gay and lesbian parents. Other issues confronting partners of gay and lesbian parents surface when the gay or lesbian relationship breaks up after years of mutual parenting. Because of the existing legal structure, the nonparent spouse typically has no recourse that would allow him or her to continue parenting (Muzio, 1996).

Unique clinical issues also exist when single gay parents enter counseling. Many of the same concerns posed by heterosexual single parents are shared by gay and lesbian parents. Because of the increased responsibilities that accompany being a parent, many gay clients complain, "I just do not 
have the time to deal with dating." In addition, the counselor needs to be aware that being a parent is often a liability to dating within the gay and lesbian community. Consequently, feelings of isolation are often intensified.

Additional issues related to counseling the gay and lesbian parent involve the interaction between parent and child. The decision to self-disclose one's homosexuality to a child is a pivotal determination that is often addressed in the therapeutic relationship (Barranti, 1998; McVinney, 1998). Counselors must be willing to discuss both the positive and negative ramifications of self-disclosure to a child and assess for appropriate social support. In certain cases, family therapy may be the most effective clinical alternative to individual counseling. As in the case of couples counseling, if the counselor is not adequately trained in family therapy, he or she needs to know referral sources who are affirming of gay and lesbian clients.

\section{CONCLUSION}

What is most surprising today is not that $10 \%-20 \%$ of gay and lesbian individuals are parents but that $80 \%-90 \%$ are not. Counselors will increasingly encounter gay and lesbian parents, or gay and lesbian individuals who want to be parents; thus, counselors need to be prepared to help these individuals with the normal challenges of parenting and with the additional challenges imposed by being both a parent and a person who is gay or lesbian. Additional research is needed to help counselors accurately identify the concerns of this population and develop effective interventions to meet their specific needs. Some areas of research that may be most helpful include longitudinal studies that address developmental aspects of gay and lesbian parents, research that focuses on the self-disclosure patterns of sexual minority parents, and further inquiry into differences in gay and lesbian parenting. Other implications for further research include delineating the effects of discrimination from both inside and outside the gay and lesbian community on parental efficacy.

\section{REFERENCES}

Achitenberg, R. A. (1985). Sexual orientation and the Latw. New York: Clark-Boardman.

Allen, K. R., \& Demo, D. H. (1995). The families of lesbians and gay men: A new frontier in family research. Journal of Marriage and the Family, 57, 1-17.

Bailey, M. J., Bobrow, D., Wolfe, M., \& Mikach, S. (1995). Sexual orientation of adult sons of gay fathers. Developmental Psychology, 31, 124-129.

Barranti, C. C. (1998). Social work with lesbian couples. In G. P. Mallon (Ed.), Foundations of social work practice with lesbian and gay persens (pp. 183-208). New York: Harrington Park.

Benkov, L. (1994). Reinventing the family: The emerging story of lesbian and gay parents. New York: Crown.

Bigner, J. J., \& Bozett, E. W. (1990). Parenting by gay fathers. In F. W. Bozett \& M. B. Sussman (Eds.). Homosexualty and family relations (pp. 155-175). New York: Harrington Park. 
Bigner, J. J., \& Jacobsen, R. B. (1989). The value of children to gay and heterosexual fathers. Journal of Homosexuality, 18, 163-172.

Bozette, F. W. (1979). Gay fathers: Evolution of the gay-father identity. American Journal of Orthopsuchiatry, 51, 552-559.

Bozett, F. W. (1980). Gay fathers: How and why they disclose their homosexuality to their children. Family Relutions, 29, 173-179.

Bozett, E W. (1987), Gity and lesbian purents. New York: Praeget.

Cain, R. (1991). Stigma management and gay identity development. Social Work, 36, 67-73.

Cass, V. C. (1979). Homosexual identity formation: A theoretical model. Journal of Homosexuatity, 4. $219-235$.

Chickering. A. W. (1993). Educasion and sdentity. San Francisco: Jossey-Bass.

City of Los Angeles Task Force on Family Diversity. (1988). Final repart: Strengthening families-A madel for community action. Los Angeles, CA: Author.

Colberg. M. (1996). With open arms: The emotional journcy of lesbian and gay adoption. In the Family, 2, 6-11.

Dindia, K. (1998) Going into and coming out of the closet: The dialectics of stigma disclosure. In B. M. Montgomery \& L. A. Baxter (Eds.). Dialectical approathes to studying personal relationships (pp. 83-108). Mahwah, NJ: Erlbaum.

Durne, E. J. (1987). Helping gay futhers come out to their children. Joumal of Homosexualito 14, 213-222.

Erikson, E, H. (1963). Childhood and society. New York: Norton.

Fassinger. R. E. (1991). The hidden minority: lesues and challenges in working with lesbian women and gay men. The Counseling Psychologist. 19, 157-176,

Fassinger, R. E. \& Miller, B. A. (1996). Validation of an inclusive model of sexual minority identity formation on a sample of gay men. Journal of Homosexuality, 32, 53-78.

Flaks, D. K., Ficher, 1., Masterpasqua, F., \& Joseph, G. (1995). Lesbians choosing motherhood: A comparative study of lesbian and heterosexual patents and their children. Developmental Psychology, 31, 105-114.

Fraser, 1. H., Fish, T. A., \& Mackenzic, T. M. (1995). Reactions to child custody decisions involving homosexual and heterosexual parents. Canadian fournal of Behavinural Science, 27, 52-63.

Frommer, M. S. (1996). The right fit: A gay man's quest for fatherhood. In ste Family, 2, 12-16.

Green, E. J. (1978). Lesbian mothers and their children. Journal of Homosexwislity, 8, 114-128.

Harrison, A. O., Wilson, M. N., Pine, C. J., Chan, S. Q., \& Buriel, R. (1990). Family ecologies of ethnic minority children. Child Development, 61. 347-362.

Havighurst, R. J. (1973). History of developmental psychology: Socialization and personality development through the life span. In P. B. Baltes \& K. W. Schaic (Eds.), Life-span developmental psychalogy. New York: Academic.

Ivey, A. E. (1991). Developmental strategies for helpers: Individual, family, and network interventions. Pacific Grove, CA: Brooks/Cole.

Kleber, D., Howell, R, \& Tibbits-Kleber. A. (1986). The impact of parental homosexuality in child custody cases: A review of the literature. Bulletin of the American Academy of Bystriatry and the Lanl 14, 81-87.

Mallon, G. P. (1998). Foundations of social uvork pnactice utith kbbian and gay perons. New York: Harrington Park.

Marcia. J. E. (1987). The identity status approach to the study of ego identity development. In T. Honess \& K. Yardley (Eds.), Self and identity; Perspestives across the lifospan, London: Routledge \& Kegan Paul.

Masters, W. H., \& johnson, V. E. (1979). Homosextality in perspective. Boston: Littie \& Brown.

McPherson, D. (1993). Gaty parenting couples: Parensing amangements, arrangement satisfaction, and relationship satisfiaction. Unpublished doctoral dissertation, Pacific Graduate School of Psychology, Portland, OR.

McVinney, L. D. (1998). Social work pracrice with gay male couples. In G. P. Mallon (Ed.), Foundarion of social work practice with lesbian and gaty persons (pp. 1209-1228). New York: Harrington Park.

Mitanda, J. \& Storms. M. (1989). Psychological adjustment of lesbians and gay men. Journal of Counseling of Development, 68, 41-45.

Mitchell, V. (1996). Two moms: Contriburion of the planned lesbian family and the deconstruction of gendered parenting. In J. Laird \& R. J. Green (E.ds.), Lesbians and gays in couples and families: A handbook for therapists (pp. 343-357). San Francisco: Jossey-Bass.

Muzio. C. (1996). Lesbian co-parenting; On being/being the invisible mother. Smith College Studies in Social Work. 63(3), 215-229.

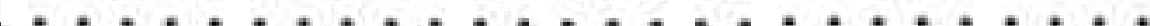


Noble, E. (1987). Having your baby by donor insemination. Boston: Houghton Mifflin.

Papalia, D. E., Camp, C. J.. \& Feldman, R. D. (1996). Adult develofment and aging. New York: McGraw-Hill.

Patterson, C. J. (1992). Children of lesbian and gay parents. Child Development. 63, 1025-1042.

Patterson, C. J. (1994). Lesbian and gay couples considering parenthood: An agenda for research, service and advocacy. In L. A. Kurdek (Ed.). Social services for gay and lesbian couples (pp. 33-56). Binghamton, NY: Harrington Park.

Perry, W. G. (1970). Forms of intellectual and ethical development in the college years. New York: Holt, Rinchart \& Winston.

Pies, C. (1990). Lesbians and the choice to parent. In F. W. Bozett \& M. B. Sussman (Eds.), Homosexualty and family relations (pp. 137-154). New York: Harrington Park.

Ricketts, W. (1991). Lesbian and gay men as fosser parents. Portland, MN: National Resource Center for Management and Administration.

Ricketts, W.. \& Achtenberg, R. (1990). Adoption and foster parenting for lesbians and gay men: Creating new traditions in family. Homosextality and family relations (pp. 119-136). New York: Harrington Park,

Riddle, D., \& Arguelles, M. (1981). Children of gay parents: Homophobia's victims. In I. Stuart \& L. Abt (Eds.), Children of separation and divore (pp. 174-197). New York: Van Nostrand Reinhold.

Robertson, L. (1996, September 3). All clear over surrogate baby. The Glasgow Herald, p. 1.

Robinson, B. E., \& Barret, R. L. (1986). The developing father: Emerging roles in contemporary society. New York: Guilford.

Rohrbaugh, J. B. (1988). Choosing children: Psychological issues in lesbian parenting. Women and Therapy, $8,51-63$.

Rothberg, B., \& Weinstein, D. L. (1996). A primer on lesbian and gay families. In M. Shernoff (Ed.), Human services for gay people: Clinical and community practice (p. 102) Binghamton, NY: Haworth.

Schaic, K. W., \& Geiwitz, J. (1982). Readings in adult development and aging. Boston: Little, Brown.

Sears, J. T. (1991). Educators, homosexuality, and homosexual students: Are personal feelings related to professional beliefs? Journal of Homosexuality, 22, 29-79.

Shernoff, M. (1996). Gay men choosing to be fathers. In M. Shernoff (Ed.), Human services for gaty people: Clinical and community practice (pp. 41-54). Binghamron, NY: Haworth.

Troiden, R. R. (1989). The formation of homosexual identities. Journal of Homosexuality, 17, 43-73. 